\title{
Clinicopathologic features of triple negative breast cancers: an experience from Pakistan
}

\author{
Atif Ali Hashmi ${ }^{1}$, Muhammad Muzzammil Edhi' ${ }^{2}$, Hanna Naqvi', Naveen Faridi ${ }^{1}$, Amna Khurshid ${ }^{1}$ \\ and Mehmood Khan ${ }^{3 *}$
}

\begin{abstract}
Background: Young age breast cancers are quite prevalent in our setup, a significant number of which exhibit triple negative phenotype. These cancers behave in an aggressive fashion and unresponsive to targeted adjuvant therapy. We aimed to evaluate clinical and histopathologic features of triple negative cancers in our population.

Methods: We retrospectively evaluated 1104 cases of primary breast cancers. Immunohistochemical studies for ER, PR and Her2neu followed by Her2neu gene amplification by FISH testing were done to identify 205 (18.6\%) cases of triple negative breast cancers.

Results: Mean age for triple negative breast cancer patients was 48.4 years $( \pm 12.3)$ and $60 \%$ of patients were diagnosed at less than 50 years of age. Although ductal carcinoma was the most frequent histologic type, a meaningful number of cases exhibited metaplastic and medullary like features ( $10.7 \%$ and $5.9 \%$ respectively). Similarly geographic necrosis involving more than $40 \%$ of tumor and extensive lymphocytic infiltration was a considerable finding. Mean Ki67 index was $45.2 \%( \pm 25.2)$ and as a reflection of tumor grade, a significantly higher proportion of cases (66.3\%) were under high risk Ki67 category (>30\%).

Conclusion: Triple negative breast cancers typify high grade breast cancers with a higher frequency of atypical medullary and metaplastic histologies. Their prevailing occurrence at a younger age raises question of under lying BRCA mutations in our population. Therefore, we suggest that risk factors including BRCA 1 mutations should be uncovered in reproductive age group breast cancers especially those disclosing basal like phenotype.
\end{abstract}

Virtual slides: The virtual slide(s) for this article can be found here: http://www.diagnosticpathology.diagnomx.eu/vs/ 9042440621102239.

Keywords: Triple negative breast cancer, Basal breast cancer, ER, PR, Her2neu

\section{Introduction}

Gene expression profiling studies put a new insight into breast cancer classification beyond traditional histologic sub-typing and grading. These newly defined luminal, Her2neu and basal molecular subtypes of breast cancer in addition to being a powerful indicator of prognosis are also predictive of adjuvant hormonal and chemotherapeutic response [1,2]. Among these, basal type breast cancers are associated with worst prognostic and clinical profile especially if not detected at an early age. They comprise $15-20 \%$ of breast cancers and show low expression of ER, PR and Her2neu genes. Basal cancers

\footnotetext{
* Correspondence: mehmoodkhan955@yahoo.com

${ }^{3}$ Dhaka Medical College, Dhaka, Bangladesh

Full list of author information is available at the end of the article
}

derived its name by its origin from basal epithelial cells of breast tissue and are thus typified by high expression of basal epithelial cytokeratins [3]. Basal cancers are affiliated with an abnormal DNA damage response pathway with an ancillary elevated proliferation gene expression. Although basal cancer subtype was originally defined by gene expression profiling, however it was suggested that an analogous ascertainment can be made by immunohistochemical (IHC) techniques [4]. According to that annotation, triple negativity for ER, PR and Her2neu elucidate basal type breast cancers with high expression of basal cytokeratins [5]. Majority of triple negative breast cancers by IHC were found to be of basal like phenotype by gene expression profiling, however Fluorescent Insitu hybridization (FISH) testing is recommended by 
College of American Pathologists (CAP) for intermediate IHC expression of Her2neu [6].

Breast cancer is most frequent cancer of women in Karachi, accounting for one-third of the cancers in the females. The incidence of breast cancer is extremely high in Karachi and second highest in Asia after Israel [7]. A total of 698 cases of breast cancer were registered from Karachi south over a duration of 3 years from 1995-1997 with a crude incidence rate of $33.1 \%$. The incidence of reproductive age breast cancer in karachi is the highest reported globally [8].

Basal cancers have a unique demographic and racial profile, with high rate of occurrence contemplated in Asian and African American women [9]. A comparative study conducted in United States revealed a higher frequency of hormone receptor negative breast cancers in Asian women compared to Caucasians [10]. Analogously a higher frequency of basal cancers was also demonstrated in Chinese women [11]. While the exact incidence of basal cancers in Pakistani population is not characterized, it is well established that frequency of reproductive age breast cancer is considerably higher than the western population [12,13]. As a reason for this happening is not known and pathologic parameters of younger age breast cancer is not well elucidated in our setup, therefore we aimed to determine the frequency and clinicopathologic parameters of triple negative breast cancers in our population which usually show a targeted racial and age preference.

\section{Methods}

We retrospectively analyzed 1104 cases of primary breast cancers treated at Liaquat National Hospital from January 2010 till December 2012 over duration of 3 years. Approval from institutional research and ethical review committee was taken antecedent to conducting the study. Patients after provisional diagnosis of breast cancer underwent trucut biopsies, modified radical mastectomy and breast conservative surgeries. All non-epithelial tumors were excluded from the study. Histologic type of tumors was determined by WHO classification of breast tumors and graded by Modified Bloom-Richardson grading system. Immunohistochemical testing for ER, PR, Her2neu and Ki67 was applied on all cases. A total of 158 out of 1104 cases were negative with ER and PR antibodies and either negative or weak $(1+)$ positive with Her2neu antibody. Total 68 cases were intermediate $(2+)$ positive for Her2neu with negative ER and PR. Therefore subsequent FISH testing was performed on these 68 cases, out of which 19 cases showed Her2neu gene amplification, 2 cases were equivocal and 47 cases were negative for Her2neu gene amplification.

One representative section from each tumor was selected for immunohistochemical staining for ER, PR, HER2neu and Ki67. Immunohistochemical testing was done by DAKO envision method according to manufacturers recommendations. The results for ER and PR were scored in a semi quantitative fashion incorporating both the intensity and the distribution of specific staining [14]. For each tissue a value designated as H-SCORE was derived by summing up the percentage of cells staining intensity multiplied by the weighted intensity of staining. An H-SCORE of less than 50 was established as negative, whereas an $\mathrm{H}$-score of $>50$ is considered as positive for ER and PR expression.

HER2neu were scored based on the intensity and percentage of positive cells on a scale of 0 to $3+$. Cases were reported 0 (negative) if no staining or membrane staining in less than $10 \%$ of invasive tumor cells was seen, $1+$ (negative) if faint/barely perceptive membrane staining was detected in more than $10 \%$ of invasive tumor cells, $2+$ (positive) if weak to moderate complete membrane staining in more than $10 \%$ tumor cells or $<30 \%$ with strong complete membrane staining, or $3+$ (positive) if strong complete membrane staining in more than $30 \%$ invasive tumor cells was seen [15].

Ki-67 immunoreactivity was recorded as continuous variables, based on the proportion of positive tumor cells (0\%-100\%). Besides evaluating Ki-67 as continuous variable, levels of Ki-67 were quantified as high Ki-67 (immunostaining $\geq 30 \%$ ), low (immunostaining $<15 \%$ ) and intermediate (between 16 to $30 \%$ ) approach adopted by St Gallen International Expert Consensus [16,17].

Cases with intermediate $(2+)$ expression of Her2neu underwent subsequent FISH testing for Her2neu gene amplification. FISH testing was performed using FDA approved Path Vysion Her2 DNA Probe kit according. Paraffin embedded tissues were cut at 5 microns and mounted on positively charged glass slides. Four slides were prepared, with one slide stained with $\mathrm{H}$ and $\mathrm{E}$, the selection of tissue and the identification of target areas on the $\mathrm{H}$ and $\mathrm{E}$ stained slides was performed by a pathologist. Using the $\mathrm{H}$ and $\mathrm{E}$ slide as reference, target area was etched with a diamond tipped scriber on the back of the unstained slide to be assayed. Glass slides with paraffin embedded tissue sections were baked at $56 \mathrm{C}$ overnight. Tissue was then processed in xylene, ethanol, purified water and wash buffer according to manufacturer recommendations. Probe mixture was applied to the target area of the tissue on slide, sealed with rubber cement and then incubated in thermobrite for hybridization. After post-hybridization buffering, DAPI (counter stain) was applied. Slides were analyzed by two technologists, interpreting 60 interphase nuclei using fluorescence microscope equipped with appropriate excitation and emission filters allowing the visualization of the orange and green fluorescent signals.

Results were expressed as the ratio of Her2 signals as compared to CEP 17 signals according to ASCO/CAP 
guidelines. A HER2: CEP 17 ratio of less than 1.8 was considered as absence of HER2 gene amplification. A HER2: CEP 17 ratio from 1.8-2.2 was taken as equivocal and ratio of $>2.2$ was considered gene amplification when there were greater than 6 HER2 signals per nucleus.

\section{Results}

Out of 1104 cases of breast cancer identified during the study period, 205 cases (18.6\%) were triple negative for ER, PR and Her2neu or non-amplified on Her2neu gene amplification by FISH testing and therefore included in the study. Out of these 205 cases, 110 patients underwent primary surgery either radical or conservative while in 95 cases trucut biopsy was done followed by neoadjuvant therapy. Mean age for the patients was 48.4 years $( \pm 12.3)$. A significant number of cases were diagnosed at a younger age less than 50 years $(60 \%)$. Very few cases were at pT1 stage (12.7\%), while most of them were either pT2 or pT3. Although ductal carcinoma was the most frequent histologic type, a meaningful number of cases exhibited metaplastic and medullary like features (10.7\% and $5.9 \%$ respectively) (Figure 1 ). Similarly geographic necrosis involving more than $40 \%$ of tumor and extensive lymphocytic infiltration was a considerable finding. Mean Ki67 index was $45.2 \%( \pm 25.2)$ and as a reflection of tumor grade, a significantly higher proportion of cases (66.3\%) were under high risk Ki67 category (>30\%) as defined by St. gallen international expert consensus recommendations. Lymph node metastasis and lymphovascular invasion were seen in $48.2 \%$ and $27.3 \%$ cases respectively. Detailed clinicopathologic characteristics of the studied cases are presented in [Table 1]. Correlation of tumor size with lymph node status, Ki67 index and tumor grade are shown in [Table 2], which shows a positive significant correlation between tumor size and lymph node status. Correlation of Ki67 index with tumor size, lymph node status and tumor grade are shown in [Table 3].

\section{Discussion}

Breast cancer is a heterogeneous disease encompassing numerous distinct histologic and gene profile based subtypes. Triple negative breast cancers represent one of the most aggressive phenotype with discrete risk factors and ominous prognostic significance. Our data represents the first study highlighting the clinical, histopathologic and prognostic factors of basal like breast cancers in our population.

Several studies evaluated the risk factors associated with basal like breast cancers including age, race, ethnicity, reproductive and parity history, breast feeding and obesity. Trivers KF et. al in a study involving 476 patients evaluated socio-demographic and reproductive
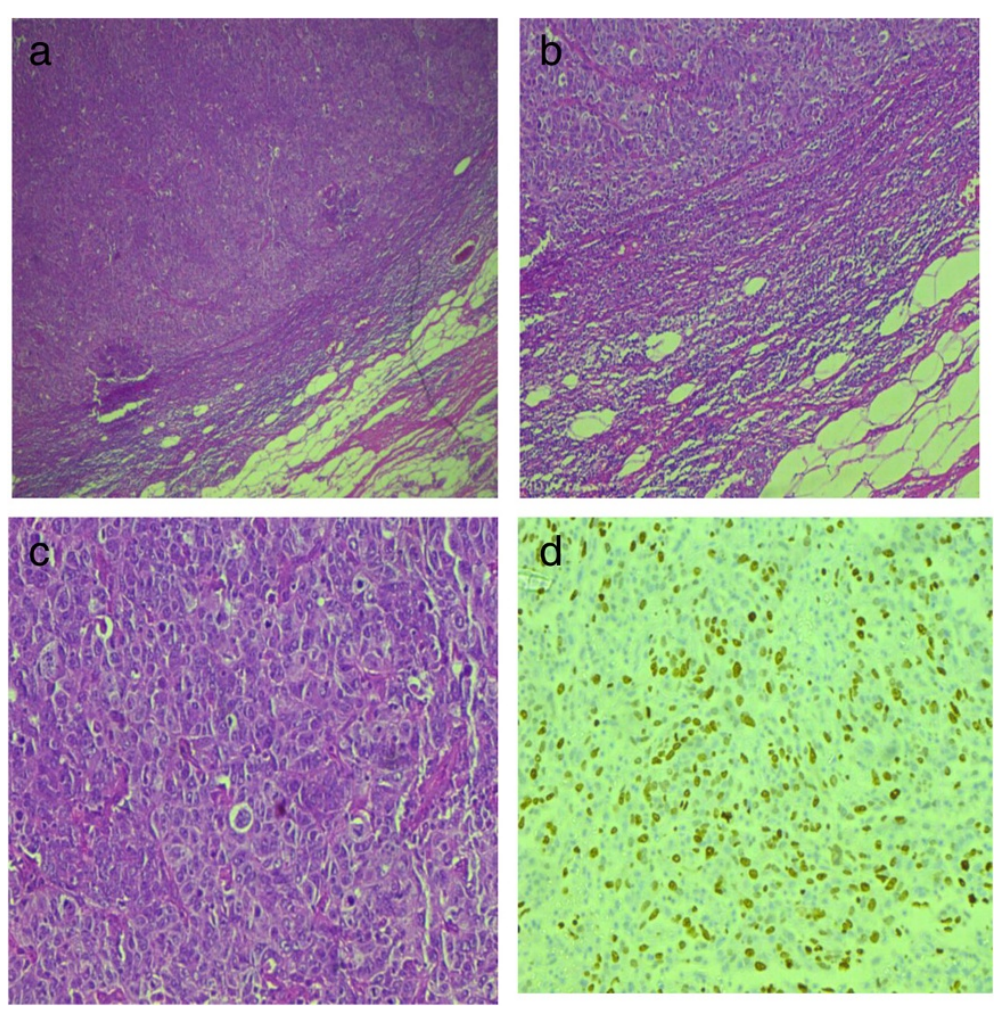

Figure 1 Micrographs of carcinoma with medullary features. (a-c) Infiltrating carcinoma with circumscribed pushing borders, dense peripheral lymphoid infiltrate and syncytial growth pattern. (d) High Ki-67 index in tumor cells. 
Table 1 Clinicopathologic features of triple negative breast cancers

\begin{tabular}{|c|c|}
\hline Variable & $\mathrm{n}=\mathbf{2 0 5}$ \\
\hline \multicolumn{2}{|l|}{ Age at dignosis } \\
\hline Mean \pm SD (years) & $48.4 \pm 12.3$ \\
\hline \multicolumn{2}{|l|}{ Age specific groups, $\mathrm{N}(\%)$} \\
\hline$<30$ years & $15(7.3 \%)$ \\
\hline $31-40$ years & $47(22.9 \%)$ \\
\hline $41-50$ years & $61(29.8 \%)$ \\
\hline $51-70$ years & $70(34.1 \%)$ \\
\hline$>70$ years & $12(5.9 \%)$ \\
\hline \multicolumn{2}{|l|}{ Tumor size } \\
\hline Mean $\pm S D(m m)$ & $38.2 \pm 16.2$ \\
\hline \multicolumn{2}{|l|}{ Size specific groups, n (\%) } \\
\hline$\leq 2.0 \mathrm{~cm}(\mathrm{pT} 1)$ & $14(12.7 \%)$ \\
\hline 2.0-5.0 cm (pT2) & $81(73.6 \%)$ \\
\hline$>5.0 \mathrm{~cm}(\mathrm{pT} 3)$ & $15(13.6 \%)$ \\
\hline Without surgery/trucut biopsy ${ }^{\$}$ & 95 \\
\hline \multicolumn{2}{|l|}{ Histological type, n (\%) } \\
\hline Infiltrating ductal carcinoma (NOS) & $158(77.1 \%)$ \\
\hline Infiltrating lobular carcinoma & $05(2.4 \%)$ \\
\hline Metaplastic carcinoma & $22(10.7 \%)$ \\
\hline Invasive papillary carcinoma & $07(3.4 \%)$ \\
\hline Infiltrating carcinoma with medullary features & $12(5.9 \%)$ \\
\hline Missed ductal and lobular carcinoma & $01(0.5 \%)$ \\
\hline
\end{tabular}

Histologic grade, $\mathbf{n}(\%)$

Grade I (well differentiated)

Grade II (moderately differentiated)

$10(4.9 \%)$

Grade III (poorly differentiated)

Lymphovascular invasion, $\mathrm{n}(\%)$

Present

Not present

Cannot be assessed ${ }^{\$}$

$30(27.3 \%)$

$80(72.7 \%)$

95

Necrosis, $\mathbf{n}(\%)$

Geographic necrosis involving $>40 \%$ of tumor

Necrosis involving $<40 \%$ of tumor

Necrosis is absent

$34(30.9 \%)$

$72(65.5 \%)$

Cannot be completely assessed

Lymphocytic infiltration, $\mathrm{n}$ (\%)

Extensive lymphocytic infiltration

$65(31.7 \%)$

$130(63.4 \%)$
Table 1 Clinicopathologic features of triple negative breast cancers (Continued)

\begin{tabular}{|c|c|}
\hline Mild to moderate lymphocytic infiltration & 89 (80.9\%) \\
\hline Cannot be completely assessed ${ }^{\lessgtr}$ & 95 \\
\hline \multicolumn{2}{|l|}{ Lymph node status, $n$ (\%) } \\
\hline Negative lymph nodes (NO) & $57(51.8 \%)$ \\
\hline 1-3 positive lymph nodes (N1) & $24(21.8 \%)$ \\
\hline 4-9 positive lymph nodes (N2) & $11(10.0 \%)$ \\
\hline$\geq 10$ positive lymph nodes (N3) & $18(16.4 \%)$ \\
\hline Lymph nodes dissection not done & 95 \\
\hline \multicolumn{2}{|l|}{ Extranodal extension, $\mathrm{n}(\%)$} \\
\hline \multicolumn{2}{|l|}{ Present } \\
\hline Not present & $15(13.6 \%)$ \\
\hline \multirow{2}{*}{ Lymph nodes dissection not done } & $95(86.4 \%)$ \\
\hline & 95 \\
\hline \multicolumn{2}{|l|}{ Ki-67 proliferation index } \\
\hline Mean \pm SD (\%) & $45.2 \pm 25.2$ \\
\hline \multicolumn{2}{|l|}{ i-67 proliferation index, (categories), n (\%) } \\
\hline \multicolumn{2}{|l|}{$\leq 15 \%$ (low) } \\
\hline \multicolumn{2}{|l|}{ 16-30\% (Intermediate) } \\
\hline & $32(15.6 \%)$ \\
\hline \multirow[t]{2}{*}{$>30 \%$ (High) } & $37(18.0 \%)$ \\
\hline & $136(66.3 \%)$ \\
\hline \multicolumn{2}{|l|}{ Type of surgery $n$ (\%) } \\
\hline \multicolumn{2}{|l|}{ Modified radical mastectomy } \\
\hline Breast conservation surgery & \\
\hline
\end{tabular}

$90(43.9 \%)$

Surgery not done/trucut biopsy $15(7.3 \%)$

Laterality $\mathbf{n}$ (\%)

Right

$94(45.9 \%)$

Left

$111(54.1 \%)$

${ }^{5}$ Cases are of trucut biopsies without surgery.

characteristics of breast cancers. Their data revealed that hormone receptor negative breast cancers were associated with black race and young age at first birth. They also affirmed that history of recent birth and obesity as being risk factors for these cancers [18]. Phipps AL et al. suggested nulliparity as a protective factor for triple negative breast cancer, although they didn't find a significant association with breast feeding and oral contraceptive usage [19]. Risk factors for basal like cancers were also explored in Carolina breast cancer study. They found increased parity, younger age at first term full-term pregnancy, longer duration of breastfeeding, increasing number of children breastfed, 21 (19.1\%) and increased duration of breastfeeding per child each associated with an overall decrease in the risk of basal 
Table 2 Correlation of tumor size with lymph node status, Ki67 index and tumor grade

\begin{tabular}{llllll}
\hline Sr. no. & \multicolumn{5}{c}{ Tumor size } \\
\cline { 2 - 6 } & & T1 & T2 & T3 & p-value \\
\hline 1. & Lymph node status & & & & \\
& Positive & 3 & 35 & 10 & 0.036 \\
& Negative & 12 & 45 & 5 & \\
2. & Ki67 index & & & & \\
& Low & 4 & 14 & 8 & \\
& Intermediate & 3 & 18 & 49 & 0.876 \\
& High & 8 & 49 & 8 & \\
3. & Tumor grade & & & & \\
& Gll & 2 & 11 & 4 & 0.422 \\
& Glll & 13 & 70 & 11 & \\
\hline
\end{tabular}

like breast cancers [20]. Although we did not evaluated all these parameters in our study but we found a higher frequency of basal like cancers in reproductive age group women.

Some authors suggested that triple negative and basal like breast cancers are not entirely similar entities. Basal like cancer is a molecular defined category of breast cancer with expression of unique set of genes involving epidermal growth factor (EFGR), basal cytokeratins (CK) 5/ 6, proliferation gene clusters and low expression of hormone and Her2neu genes [21]. Bertucci F evaluated gene expression profile of 172 cases of triple negative breast cancers and found $72 \%$ to express basal like phenotype [22]. Gene expression profile separated out several subtypes of triple negative cancers including two basal subtypes, immunomodulatory, mesenchymal, mesenchymal stem-like, luminal androgen, claudin-low and interferonrich subtypes [23-25]. How much these subtypes behave differently clinically is yet to be fully understood, but

Table 3 Correlation of Ki67 index with tumor size, lymph node status and tumor grade

\begin{tabular}{|c|c|c|c|c|c|}
\hline \multirow[t]{2}{*}{ Sr. no. } & \multicolumn{5}{|c|}{ Ki67 index } \\
\hline & & Low & Intermediate & High & $p$-value \\
\hline \multirow[t]{4}{*}{1.} & Tumor size & & & & \\
\hline & T1 & 4 & 3 & 8 & 0.876 \\
\hline & $\mathrm{T} 2$ & 14 & 18 & 49 & \\
\hline & T3 & 4 & 3 & 8 & \\
\hline \multirow[t]{3}{*}{2.} & Lymph node status & & & & \\
\hline & Positive & 8 & 14 & 26 & 0.245 \\
\hline & Negative & 14 & 10 & 38 & \\
\hline \multirow[t]{4}{*}{3.} & Tumor grade & & & & \\
\hline & $\mathrm{Gl}$ & 3 & 1 & 6 & 0.180 \\
\hline & Gll & 7 & 17 & 41 & \\
\hline & GIII & 22 & 19 & 89 & \\
\hline
\end{tabular}

chemotherapy is the main stay of treatment as they are generally insensitive to targeted hormonal and herceptan therapy. Phase II clinical trials are under way to fully establish the potential role of anti-EFGR therapy in triple negative breast cancers.

Kreike B et. al in a study involving 97 triple negative cases of breast cancer evaluated clinical, histological and molecular features. They found $59 \%$ of cases were below 50 years of age and $65 \%$ of tumors were above $2 \mathrm{~cm}$ in maximum dimension. Although $83 \%$ of cases showed typical ductal morphology but 3 cases were metaplastic carcinomas. Concordant with our results vast majority of tumors (86\%) had high grade morphology and heavy lymphocytic infiltrate was seen in only $12 \%$ of cases. They also evaluated p53 and EFGR status and positivity was seen in 50 and $27 \%$ of cases also pointing towards aggressive nature of these tumors [26].

Fulford LG et. al suggested specific morphologic features which were predictive of basal subtype. These included central scar, tumor necrosis, presence of spindle cell or squamous metaplasia, high total mitotic count $(>40$ per 10 high-power fields) and high nuclear-cytoplasmic ratio [27]. We also found high grade morphology and tumor necrosis in a significantly higher number of cases.

We found a higher frequency of metaplastic histology in our study (Figures 2 and 3). Metaplastic carcinoma itself is a heterogenous group of tumors including sarcomatoid [28], squamous cell [29], adenosquamous [30], mucoepidermoid, matrix producing [31], metaplastic carcinoma with osteoclast like giant cells [32] and low grade fibromatosis like spindle cell carcinoma [33]. We encountered 10 cases of adenosquamous carcinoma, 8 of matrix producing and 4 cases of sarcomatoid carcinoma. These three categories are among the most aggressive subtypes of metaplastic carcinoma, again pointing towards the adverse morphologic characteristics of triple negative tumors. Reis-Filho JS et. al in a study involving 65 cases of metaplastic carcinoma found $91 \%$ to be of basal like phenotype irrespective of specific subtype [34]. Our results are in agreement with these findings.

We also found 12 cases in our study with medullary like features including high grade histology, lack of insitu component, pushing borders, syncytial growth pattern and dense lymphocytic infiltration (Figure 1). Gene expression profiling studies depicted this notion that medullary like carcinomas belong to basal subgroup inspite of being associated with a better prognosis [35].

Our study validated the strong association of triple negative cancers with tumor grade and proliferative index. Methodology of Ki67 index has not been standardized yet and different cut off points were used in different studies to designate high Ki67 index (5-30\%) $[36,37]$. We therefore used 2 cut off points to stratify Ki67 index into 3 categories; the approach advised by St. 


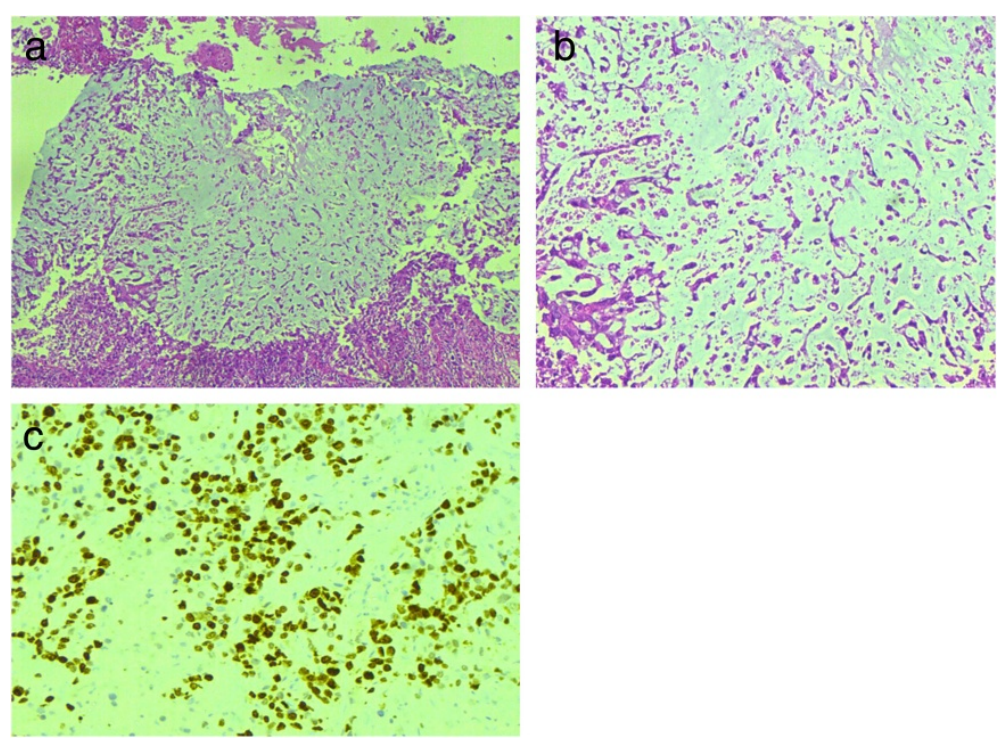

Figure 2 Micrographs of metaplastic carcinoma, matrix producing type. (a-b) Tumor cells producing abundant myxoid matrix. (c) Microphotograph showing high Ki-67 index.

Gallen International Expert Consensus. By categorizing Ki67 index into three categories in our study, a significantly higher proportion of triple negative cancers fell under the umbrella of high risk Ki67 index (66.3\%). Spitale A. et al. in a study involving 90 basal cancers also found similar association in Ticino breast cancer registry based study with more than $75 \%$ of basal cancers having Ki67 index greater than 20\% [38]. This observation is supported by high expression of proliferation gene clusters seen in gene expression profiling studies $[39,40]$.

In our study, lymph node metastasis at the time of diagnosis was found in $48.2 \%$ of cases. Vallejos et. al in a study involving 255 basal like cancers found lymph node positivity in $54.9 \%$ of cases [41]. Blows FM et. al in a collaborative review of 1645 triple negative breast cancer subdivided them into basal and non-basal phenotypes on the basis of CK5/6 and EFGR positivity. In the basal subgroup lymph node metastasis was seen in $40 \%$ of cases while non-basal triple negative phenotype exhibited lymph node metastasis in $46 \%$ of patients [42].

A morphologic study of basal cancers in Turkish population revealed that all medullary and $55.6 \%$ of metaplastic carcinomas showed basal phenotype which is concordant with our findings. Moreover they found an increased prevalence of basal cancers in younger age group. Morphologic features associated with basal cancers in their study included high nuclear grade, increased mitotic activity, geographic necrosis, pushing border of invasion and stromal lymphocytic response. Among IHC markers, vimentin was positive in 53.2\% and CK 14 in $27.7 \%$ of cases [43].

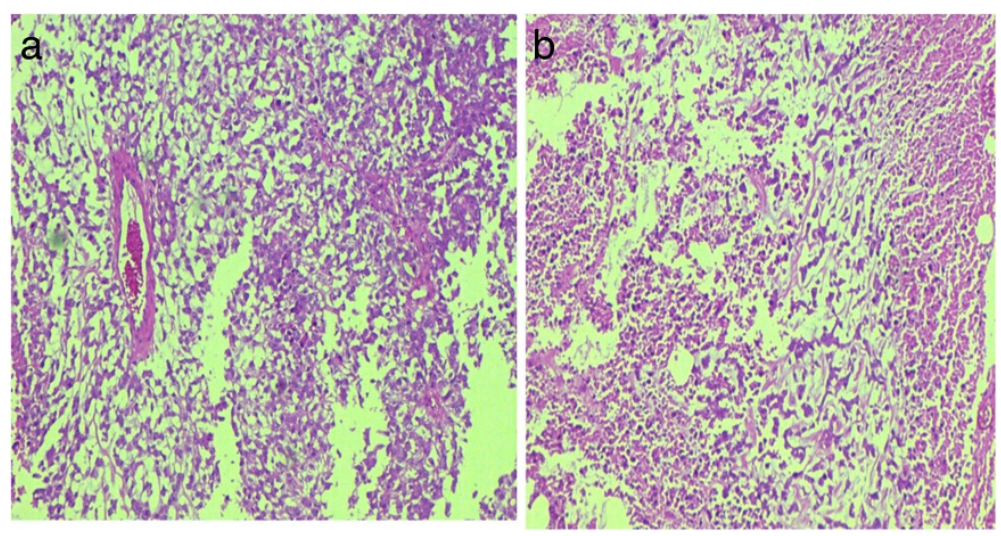

Figure 3 Micrographs showing metaplastic carcinoma. (a-b) Matrix producing type with area of necrosis. 
Triple negative cancers are a heterogeneous group of tumors with slightly different prognostic profiles. Therefore various markers were assessed to predict the prognosis in triple negative cancers. Markers which were found to be associated with poor prognostic profile in triple negative cancers include CARM1, TTF1 and SBEM. Coactivatorassociated arginine methyltransferase 1 (CARM1) belongs to protein arginine methyltransferase family. CARM1 was found to be to be expressed in 57\% of triple negative cancers and was associated with high tumor grade [44]. Thyroid transcription factor 1 (TTF1) is marker of lung and thyroid origin. Expression of TTF1 was also demonstrated in basal phenotype breast cancers. TTF1 expression was co-related with high tumor grade, lymph node metastasis and vascular invasion [45]. Similarly small breast epithelial mucin (SBEM) which has been implicated in tumor genesis and micrometastasis in breast cancer is associated with poor prognostic profile in triple negative breast cancer. SBEM expression was found to be highly co-related with higher tumor size, grade, nodal status, TNM stage and Ki67 index. Moreover multivariate analysis showed that patients with high expression of SBEM had higher risk of tumor recurrence and mortality [46]. Apart from IHC expression of various markers, role of microRNAs (miRNAs) were also evaluated in triple negative breast cancers. MiR-34b negatively co-relates with disease free survival and overall survival in triple negative cancers [47]. Laurinavicius A et. al evaluated multiple IHC markers in breast cancer. They found a high expression of p16 in triple negative breast cancers [48].

Gene expression profiling studies are not widely available in our country and cannot be performed on every case of breast cancer. Immunohistochemical studies are relatively less expensive and therefore can be performed for initial segregation of cases into specific expression profiles. Based on morphology and immunohistochemical profile, genetic studies can be performed to identify at risk families as an effective preventive measure.

Risk factors for specific morphologic subtypes of breast cancers have not been substantiated yet. Unlike smoking induced squamous metaplasia which is considered a premalignant change in bronchial epithelium, squamous metaplasia in ductal epithelium of breast is not considered pre-malignant. On the other hand, as most of the metaplastic carcinomas have been showed to harbor basal phenotype, underlying BRCA mutations and familial predisposition may play a role.

We analyzed 1104 breast cancer patients, out of which 205 cases exhibited triple negative phenotype with a frequency of $18.6 \%$. Compared to international data, only Chinese, African Americans and Peruvians had a greater frequency of triple negative cancers than ours with a figure of $21.5 \%, 21.5 \%$ and $21.3 \%$ respectively $[11,49]$. The frequency of triple negative cancers in Caucasians,
Australians and UK population was found to be low with a frequency of $12.5 \%, 14 \%$ and $13 \%$ respectively [50,51].

Another significance of basal like breast cancers lies with its association with BRCA 1 mutations. It was shown that, more than $80 \%$ breast cancers occurring in women with BRCA 1 mutation have a basal like profile. Although most basal cancers are sporadic, they are also associated with an abnormal BRCA 1 pathway [52-54]. Although young age breast cancers are quite prevalent in our population, however genetic testing including BRCA mutations were not widely done in our population. Therefore we suggest that risk factors associated with triple negative breast cancers especially those occurring in a younger age group with metaplastic and medullary histologies should be sought including underlying BRCA 1 mutations. In addition evaluation of EFGR mutations and potential role of EFGR therapy in basal like cancers should also be addressed.

\section{Conclusion}

Triple negative breast cancers typify high grade breast cancers with a higher frequency of atypical medullary and metaplastic histologies. Their prevailing occurrence at a younger age raises question of under lying BRCA mutations in our population. Therefore, we suggest that risk factors including BRCA 1 mutations should be uncovered in reproductive age group breast cancers especially those disclosing basal like phenotype.

\section{Competing interests}

The authors declare that they have no competing interests.

\section{Authors' contributions}

$\mathrm{AAH}$ : main author of manuscript, have made substantial contributions to conception, design and acquisition of data. MME: main author of manuscript, have made substantial contributions to conception and design, or acquisition of data, or analysis and interpretation of data. HN: revising it critically for important intellectual content. NF: revising it critically for important intellectual content. AK: have given final approval of the version to be published. MK: have been involved in drafting the manuscript or revising it critically for important intellectual content. All authors read and approved the final manuscript.

\section{Acknowledgements}

We gratefully acknowledge all staff members of Pathology department, Liaquat National Hospital, Karachi, Pakistan for their help and cooperation.

\section{Author details}

${ }^{1}$ Department of Histopathology, Liaquat National Hospital and Medical College, Karachi, Pakistan. ${ }^{2}$ Liaquat National Hospital and Medical College, Karachi, Pakistan. ${ }^{3}$ Dhaka Medical College, Dhaka, Bangladesh.

Received: 9 October 2013 Accepted: 5 January 2014

Published: 28 February 2014

\section{References}

1. Sørlie T, Perou CM, Tibshirani R, Aas T, Geisler S, Johnsen H, Hastie T, Eisen $M B$, van de Rijn M, Jeffrey SS, Thorsen T, Quist H, Matese JC, Brown PO, Botstein D, Lønning PE, Børresen-Dale AL: Gene expression patterns of breast carcinomas distinguish tumor subclasses with clinical implications. Proc Natl Acad Sci U S A 2001, 98:10869-10874.

2. Parker JS, Mullins M, Cheang MC, Leung S, Voduc D, Vickery T, Davies S, Fauron C, He X, Hu Z, Quackenbush JF, Stijleman IJ, Palazzo J, Marron JS, Nobel AB, Mardis E, Nielsen TO, Ellis MJ, Perou CM, Bernard PS: Supervised 
risk predictor of breast cancer based on intrinsic subtypes. J Clin Oncol 2009, 27:1160-1167. doi:10.1200/JCO.2008.18.1370.

3. Moldovan L, Mitroi A, Petrescu CM, Aschie M: Classification of breast carcinomas according to gene expression profiles. J Med Life 2013, 6(1):14-17.

4. Brenton JD, Carey LA, Ahmed AA, Caldas C: Molecular classification and molecular forecasting of breast cancer: ready for clinical application? J Clin Oncol 2005, 23:7350-7360.

5. Alshareeda AT, Soria D, Garibaldi JM, Rakha E, Nolan C, Ellis IO, Green AR: Characteristics of basal cytokeratin expression in breast cancer. Breast Cancer Res Treat 2013, 139(1):23-37.

6. Wolff AC, Hammond ME, Schwartz JN, Hagerty KL, Allred DC, Cote RJ, Dowsett M, Fitzgibbons PL, Hanna WM, Langer A, McShane LM, Paik S Pegram MD, Perez EA, Press MF, Rhodes A, Sturgeon C, Taube SE, Tubbs R, Vance GH, van de Vijver M, Wheeler TM, Hayes DF: American Society of Clinical Oncology/College of American Pathologists guideline recommendations for human epidermal growth factor receptor 2 testing in breast cancer. Arch Pathol Lab Med 2007, 131(1):18-43.

7. Bhurgri Y, Bhurgri A, Nishter S, Ahmed A, Usman A, Pervez S, Ahmed R, Kayani N, Riaz A, Bhurgri H, Bashir I, Hassan SH: Pakistan-Country profile of cancer and cancer control 1995-2004. J Pak Med Assoc 2006, 56(3):124-130.

8. Bhurgri Y, Bhurgri A, Hassan SH, Zaidi SHM, Rahim A, Sankaranarayanan R, Parkin DM: Cancer incidence in Karachi, Pakistan: first results from Karachi cancer registry. Int J Cancer 2000, 85:325-329.

9. Morris GJ, Naidu S, Topham AK, Guiles F, Xu Y, McCue P, Schwartz GF, Park PK, Rosenberg AL, Brill K, Mitchell EP: Differences in breast carcinoma characteristics in newly diagnosed African-American and Caucasian patients: a single-institution compilation compared with the National Cancer Institute's surveillance, epidemiology, and end results database. Cancer 2007, 110:876.

10. Kakarala M, Rozek L, Cote M, Liyanage S, Brenner DE: Breast cancer histology and receptor status characterization in Asian Indian and Pakistani women in the U.S.-aSEER analysis. BMC Cancer 2010, 10:191.

11. Cheng HT, Huang T, Wang W, Yue JQ, Shen N, Guo H, Li DP, Zhao QZ, Yi PF, Wang R, Wang LQ: Clinicopathological features of breast cancer with different molecular subtypes in Chinese women. J Huazhong Univ Sci Technolog Med Sci 2013, 33(1):117-121.

12. Bhurgri Y, Kayani N, Faridi N, Pervez S, Usman A, Bhurgri H, Malik J, Bashir I, Bhurgri A, Hasan SH, Zaidi SH: Patho-epidemiology of breast cancer in Karachi "1995-1997". Asian Pac J Cancer Prev 2007, 8(2):215-220.

13. Hashmi AA, Faridi N, Khurshid A, Naqvi H, Malik B, Malik FR, Fida Z, Mujtuba S: Accuracy of frozen section analysis of sentinel lymph nodes for the detection of Asian breast cancer micrometastasis-experience from Pakistan. Asian Pac J Cancer Prev 2013, 14(4):2657-2662.

14. Collins LC, Botero ML, Schnitt SJ: Bimodal frequency distribution of estrogen receptor immunohistochemical staining results in breast cancer. Am J Clin Pathol 2005, 123:16-20.

15. Wolff AC, Hammond ME, Schwartz JN, Hagerty KL, Allred DC, Cote RJ, Dowsett M, Fitzgibbons PL, Hanna WM, Langer A, McShane LM, Paik S, Pegram MD, Perez EA, Press MF, Rhodes A, Sturgeon C, Taube SE, Tubbs R, Vance GH, van de Vijver M, Wheeler TM, Hayes DF: American Society of Clinical Oncology/College of American Pathologists guideline recommendations for human epidermal growth factor receptor 2 testing in breast cancer. J Clin Oncol 2007, 25(1):118-145.

16. Goldhirsch A, Wood WC, Gelber RD, Coates AS, Thürlimann B, Senn HJ: Progress and promise: highlights of the international expert consensus on the primary therapy of early breast cancer 2007. Ann Oncol 2007, 18:1133-1144.

17. Goldhirsch A, Ingle JN, Gelber RD, Coates AS, Thürlimann B, Senn HJ Thresholds for therapies: highlights of the St Gallen International expert consensus on the primary therapy of early breast cancer 2009. Ann Oncol 2009, 20:1319-1329.

18. Trivers KF, Lund MJ, Porter PL, Liff JM, Flagg EW, Coates RJ, Eley JW: The epidemiology of triple-negative breast cancer, including race. Cancer Causes Control 2009, 20:1071. doi: 10.1007/s10552-009-9331-1.

19. Phipps Al, Chlebowski RT, Prentice R, McTiernan A, Wactawski-Wende J, Kuller LH, Adams-Campbell LL, Lane D, Stefanick ML, Vitolins M, Kabat GC, Rohan TE, Li Cl: Reproductive history and oral contraceptive use in relation to risk of triple-negative breast cancer. J Natl Cancer Inst 2011 103:470. doi: 10.1093/jnci/djr030.
20. Millikan RC, Newman B, Tse CK, Moorman PG, Conway K, Dressler LG, Smith LV, Labbok MH, Geradts J, Bensen JT, Jackson S, Nyante S, Livasy C, Carey L, Earp HS, Perou CM: Epidemiology of basal-like breast cancer. Breast Cancer Res Treat 2008, 109:123.

21. Korsching E, Packeisen J, Agelopoulos K, Eisenacher M, Voss R, Isola J, van Diest PJ, Brandt B, Boecker W, Buerger H: Cytogenetic alterations and cytokeratin expression patterns in breast cancer: integrating a new model of breast differentiation into cytogenetic pathways of breast carcinogenesis. Lab Invest 2002, 82:1525.

22. Bertucci F, Finetti $P$, Cervera N, Esterni $B$, Hermitte $F$, Viens $P$, van Diest PJ, Brandt B, Boecker W, Buerger $\mathrm{H}$ : How basal are triple-negative breast cancers? Int J Cancer 2008, 123:236. doi:10.1002/ijc.23518.

23. Lehmann BD, Bauer JA, Chen $X$, Sanders ME, Chakravarthy AB, Shyr $Y$, Pietenpol JA: Identification of human triple-negative breast cancer subtypes and preclinical models for selection of targeted therapies. J Clin Invest 2011, 121:2750. doi:10.1172/JC|45014.

24. Teschendorff AE, Miremadi A, Pinder SE, Ellis IO, Caldas C: An immune response gene expression module identifies a good prognosis subtype in estrogen receptor negative breast cancer. Genome Biol 2007, 8:R157.

25. Prat A, Parker JS, Karginova O, Fan C, Livasy C, Herschkowitz JI, He X, Perou CM: Phenotypic and molecular characterization of the claudin-low intrinsic subtype of breast cancer. Breast Cancer Res 2010, 12:R68. doi: 10.1186/bcr2635.

26. Kreike B, van Kouwenhove $M$, Horlings $H$, Weigelt B, Peterse $H$, Bartelink $H$, van de Vijver MJ: Gene expression profiling and histopathological characterization of triple-negative/basal-like breast carcinomas. Breast Cancer Res 2007, 9(5):R65.

27. Fulford LG, Easton DF, Reis-Filho JS, Sofronis A, Gillett CE, Lakhani SR, Hanby A: Specific morphological features predictive for the basal phenotype in grade 3 invasive ductal carcinoma of breast. Histopathology 2006, 49(1):22-34.

28. Carter MR, Hornick JL, Lester S, Fletcher CD: Spindle cell (sarcomatoid) carcinoma of the breast: a clinicopathologic and immunohistochemical analysis of 29 cases. Am J Surg Pathol 2006, 30:300-309.

29. Wargotz ES, Norris HJ: Metaplastic carcinomas of the breast: IV: squamous cell carcinoma of ductal origin. Cancer 1990, 65:272-276.

30. Rosen PP, Ernsberger D: Low-grade adenosquamous carcinoma: a variant of metaplastic mammary carcinoma. Am J Surg Pathol 1987, 11:351-358.

31. Hanna W, Kahn HJ: Ultrastructural and immunohistochemical characteristics of mucoepidermoid carcinoma of the breast. Hum Pathol 1985, 16:941-946.

32. Wargotz ES, Norris HJ: Metaplastic carcinomas of the breast: V: metaplastic carcinoma with osteoclastic giant cells. Hum Pathol 1990, 21:1142-1150

33. Sneige N, Yaziji H, Mandavilli SR, Perez ER, Ordonez NG, Gown AM, Ayala A: Low-grade (fibromatosis-like) spindle cell carcinoma of the breast. Am J Surg Pathol 2001, 25:1009-1016.

34. Reis-Filho JS, Milanezi F, Steele D, Savage K, Simpson PT, Nesland JM, Pereira EM, Lakhani SR, Schmitt FC: Metaplastic breast carcinomas are basal-like tumours. Histopathology 2006, 49:10-21.

35. Bertucci F, Finetti P, Cervera N, Charafe-Jauffret E, Mamessier E, Adelaide J, Debono S, Houvenaeghel G, Maraninchi D, Viens P, Charpin C, Jacquemier J, Birnbaum D: Gene expression profiling shows medullary breast cancer is a subgroup of basal breast cancers. Cancer Res 2006, 66:4636-4644.

36. Royston $P$, Altman DG, Sauerbrei W: Dichotomizing continuous predictors in multiple regression: a bad idea. Stat Med 2006, 25:127-141.

37. Viale G, Regan MM, Mastropasqua MG, Maffini F, Maiorano E, Colleoni M, Price KN, Golouh R, Perin T, Brown RW, Kovács A, Pillay K, Ohlschlegel C, Gusterson BA, Castiglione-Gertsch M, Gelber RD, Goldhirsch A, Coates AS: Predictive value of tumor Ki-67 expression in two randomized trials of adjuvant chemoendocrine therapy for node-negative breast cancer. J Natl Cancer Inst 2008, 100:207-212.

38. Spitale A, Mazzola P, Soldini D, Mazzucchelli L, Bordoni A: Breast cancer classification according to immunohistochemical markers: clinicopathologic features and short-term survival analysis in a population-based study from the South of Switzerland. Ann Oncol 2009, 20(4):628-635.

39. Rakha EA, El-Sayed ME, Reis-Filho JS, Ellis IO: Expression profiling technology: its contribution to our understanding of breast cancer. Histopathology 2008, 52:67-81. doi:10.1111/j.1365-2559.2007.02894.x.

40. Sotiriou C, Pusztai L: Gene-expression signatures in breast cancer. N Engl J Med 2009, 360:790-800.

41. Vallejos CS, Gómez HL, Cruz WR, Pinto JA, Dyer RR, Velarde R, Suazo JF, Neciosup SP, León M, de la Cruz MA, Vigil CE: Breast cancer classification 
according to immunohistochemistry markers: subtypes and association withclinicopathologic variables in a peruvian hospital database. Clin Breast Cancer 2010, 10(4):294-300.

42. Blows FM, Driver KE, Schmidt MK, Broeks A, van Leeuwen FE, Wesseling J, Cheang MC, Gelmon K, Nielsen TO, Blomqvist C, Heikkilä P, Heikkinen T, Nevanlinna H, Akslen LA, Bégin LR, Foulkes WD, Couch FJ, Wang X, Cafourek V, Olson JE, Baglietto L, Giles GG, Severi G, McLean CA, Southey MC, Rakha E, Green AR, Ellis IO, Sherman ME, Lissowska J, et al: Subtyping of breast cancer by immunohistochemistry to investigate a relationship between subtype and short and long term survival: a collaborative analysis of data for 10,159 cases from 12 studies. PLoS Med 2010, 25:7(5).

43. Cakir A, Gonul II, Uluoglu O: A comprehensive morphological study for basal-like breast carcinomas with comparison to nonbasallikecarcinomas. Diagn Pathol 2012, 7:145.

44. Cheng H, Qin Y, Fan H, Su P, Zhang X, Zhang H, Zhou G: Overexpression of CARM1 in breast cancer is correlated with poorly characterized clinicopathologic parameters and molecular subtypes. Diagn Pathol 2013, 8:129.

45. Klingen TA, Chen $Y$, Suhrke $P$, Stefansson IM, Gundersen MD, Akslen LA: Expression of thyroid transcription factor- 1 is associated with a basal-like phenotype in breast carcinomas. Diagn Pathol 2013, 8:80.

46. Liu L, Liu Z, Qu S, Zheng Z, Liu Y, Xie X, Song F: Small breast epithelial mucin tumor tissue expression is associated with increased risk of recurrence and death in triple-negative breast cancer patients. Diagn Pathol 2013, 8:71.

47. Svoboda M, Sana J, Redova M, Navratil J, Palacova M, Fabian P, Slaby O, Vyzula R: MiR-34b is associated with clinical outcome in triple-negative breast cancer patients. Diagn Pathol 2012, 7:31.

48. Laurinavicius A, Laurinaviciene A, Ostapenko V, Dasevicius D, Jarmalaite S, Lazutka J: Immunohistochemistry profiles of breast ductal carcinoma: factor analysis of digital image analysis data. Diagn Pathol 2012, 7:27.

49. Carey LA, Perou CM, Livasy CA, Dressler LG, Cowan D, Conway K, Karaca G, Troester MA, Tse CK, Edmiston S, Deming SL, Geradts J, Cheang MC, Nielsen TO, Moorman PG, Earp HS, Millikan RC: Race, breast cancer subtypes, and survival in the Carolina breast cancer study. JAMA 2006, 295(21):2492-2502.

50. Bauer KR, Brown M, Cress RD, Parise CA, Caggiano V: Descriptive analysis of estrogen receptor (ER)-negative, progesterone receptor (PR)-negative, and HER2-negative invasive breast cancer, the socalled triple-negative phenotype: a population-based study from the California cancer Registry. Cancer 2007, 109(9):1721-1728.

51. Giles GG, English DR: The Melbourne collaborative cohort study. IARC Sci Publ 2002, 156:69-70.

52. Foulkes WD, Brunet JS, Stefansson IM, Straume O, Chappuis PO, Bégin LR, Hamel N, Goffin JR, Wong N, Trudel M, Kapusta L, Porter P, Akslen LA: The prognostic implication of the basal-like (cyclin E high/p27 low/p53+/glomeruloid-microvascular-proliferation+) phenotype of BRCA1-related breast cancer. Cancer Res 2004, 64:830.

53. Foulkes WD, Stefansson IM, Chappuis PO, Bégin LR, Goffin JR, Wong $N$, Trudel M, Akslen LA: Germline BRCA1 mutations and a basal epithelial phenotype in breast cancer. J Natl Cancer Inst 2003, 95:1482.

54. Olopade Ol, Grushko T: Gene-expression profiles in hereditary breast cancer. N Engl J Med 2001, 344:2028.

\section{Submit your next manuscript to BioMed Central and take full advantage of:}

- Convenient online submission

- Thorough peer review

- No space constraints or color figure charges

- Immediate publication on acceptance

- Inclusion in PubMed, CAS, Scopus and Google Scholar

- Research which is freely available for redistribution

Submit your manuscript at www.biomedcentral.com/submit 